\title{
BANKING ON DIGITAL MONEY: Swedish Cashlessness and the Fraying Currency Tether
}

\author{
GUSTAV PEEBLES \\ The New School \\ (iD https:/ / orcid.org/0000-0002-5427-5902
}

Everyone seems to know about the austere café in the hip part of town, sing its praises, and universally declare that "all the famous people hang out there." But, in largely cashless Stockholm, it is even more distinguished by its owner's stark refusal to accept electronic payments. Considering how few Stockholmers walk around with cash, he knows that this decision radically circumscribes his potential customer base. Many times, I witnessed him or his coworkers interrogate new customers about whether they had any cash prior to brewing them some complicated coffee confection.

During those moments, he unwittingly challenged the hackneyed understanding of cash as a "cold nexus" that allows for the social separation of transactors, removing cultural and personal barriers to a potential trade. For them, it was precisely the opposite: He and his main partner knew the faces (and often the names) of everyone who came in for a cup or a light sandwich. He explained to me that, whenever he does not recognize a face, he simply alerts them to the café's idiosyncratic practice of insisting on cash payment. A significant number of new visitors walk out after learning this, since they rarely have any cash on hand. Cash, in other words, was the social glue of the establishment, whereas credit and debit 
cards marked anonymous trading, even though they have names and dense, reliable histories readily attached to them.

His commitment to cash brings to the fore the important manner in which hard cash functions as a public good - a cheaply available connective device among citizens and state that functions like a sidewalk or a highway. ${ }^{1}$ Echoing a sentiment that I encountered among experts and engaged citizens in Sweden, Ursula Dalinghaus $(2017,53)$ tells us that "concerns about cash should be placed within the broader context and more urgent question of money's role as a public good - part of a public infrastructure that everyone in society can use and access" (see also Maurer 2015; Dalinghaus 2019). As a result, the state frequently takes over monopoly production of the good to ensure its presence. In this sense, state currency operates as something vital to the market that the market itself fails to provide on its own (see Ingham 2004, 45). Like all public goods, it should provide such smooth functioning that people only notice its absence, not its presence. As Julia Elyachar $(2010,455)$ reminds us, "Infrastructure is something people tend to think about when it breaks down."

As this article will show, the Swedish Central Bank (hereinafter the Riksbank) fears that this vital "sidewalk" is breaking down. It knows_-all too well_that this essential pathway of connectivity can only sustain itself if it is nurtured, cherished, and protected by both its users (everyday citizens) and its producers (the Riksbank). As Douglas R. Holmes $(2014,1)$ explains, "the public broadly must be recruited to collaborate with central banks in achieving the ends of monetary policy." But in Sweden, a range of competitive private products are surging past public cash in popularity. As the chief of the current project to build a national e-currency, Cecilia Skingsley, announces in a YouTube video, "the Swedish people are turning their backs on our product [the Swedish krona]" (see Kivra 2018). ${ }^{2}$ Or what of one businessperson, who recounted the tale of her teenage daughter who, on being handed some hard cash, received it skeptically and queried, "What is this old-fashioned business?"

Placed in a more historical frame, we can see that Sweden's growing cashlessness is but the reignition of a centuries-old battle over "note-issuance" that has long played out between central and commercial banks the world over. Famously, central banking largely eradicated the "private issue" of currency notes, mostly in the nineteenth century (see, e.g., Grossman 2010, 162-63). Richard S. Grossman explains that, in creating the system of "fractional reserve banking" that we know so well today, central banks stopped competing with commercial banks, choosing instead to seize monopoly control over the creation of cash. In so doing, cash 
moved into the realm of public goods, with central banks becoming its producer, distributor, and guardian. Like many public good monopolies, this development was often seen as a "win-win" covenant, allowing all stakeholders - including even the commercial banks that had profited off of note-issuance-to consider it the best solution for creating stability and soundness in the otherwise turbulent marketplace created by commercial bank over-issuance.

But now, with public cash being pushed out of the marketplace, the Riksbank believes its seemingly age-old monopoly over cash is threatened. Unbeknownst to many, the funding required to provide the public good known as cash emerges from this same public good's circulation. Thanks to a little-known tax called "seigniorage," central banks often fund themselves, instead of turning to national governments for budgetary support. As Kenneth S. Rogoff $(2017,121)$ explains, "Governments enjoy considerable profits from their monopoly on paper currency, which costs next to nothing to print and yet can be spent at face value. . . The revenues from paper currency are substantial, and for central banks constitute the biggest counterargument to phasing out cash.”

Put bluntly, without seigniorage, central banks could go bankrupt. Or, as one specialist explained to me more bluntly, "seigniorage is what makes the Riksbank independent." They would, thus, suddenly find themselves subjected to the whims of rotating politicians who controlled their purse strings. Worse still, the public good of cash that they have worked so hard to sustain and nurture could eventually fall into private hands, just as states have found themselves lately handing over various other public-goods infrastructure — such as bridges, ports, and highways (like money, also vital modes of connectivity) — to private ownership.

The Riksbank thus confronts a dangerous scenario wherein its krona, a public good that solved a host of extant socioeconomic problems (see, e.g., Helleiner 2003), falls into disuse and thus hobbles the Riksbank's ability to respond nimbly to the same socioeconomic problems that it promised - via control of the currency - to keep at bay in the first place. The chart below (taken from Rogoff 2017, 127) reveals how the Swedish Riksbank is at an "all hands on deck" moment, seeing the cashless revolution as a creeping threat to its authorized monopoly on controlling the currency. With revenue from seignorage not only dwindling but actually disappearing, it therefore must quickly consider new methods for ensuring the ongoing economic stability that both citizens and banks have come to expect from it. Digitizing hard cash by giving birth to a new "e-krona" has leapt forward as one of the premier possibilities for doing so. 


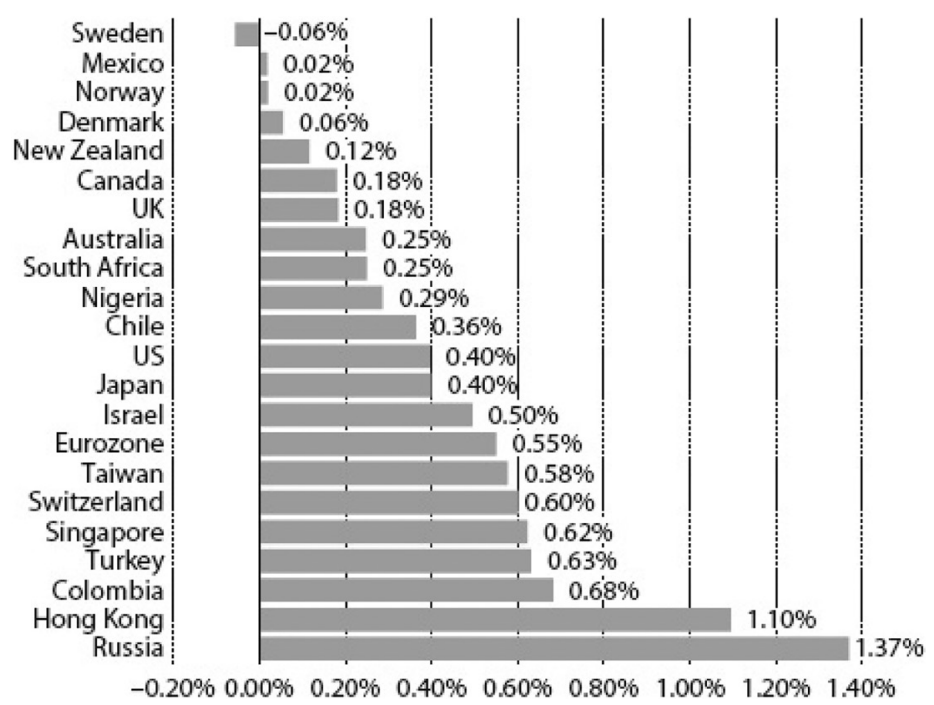

Figure 1. Seigniorage revenue/GDP, 2006-2015 average. Graph from Kenneth S. Rogoff $(2017,127)$.

In the following pages, I present ethnographic material gathered during a year of living and working in Sweden with my family. Despite my own long-standing interest in monetary reform efforts, I had not initially planned to study Sweden's cashlessness - until a group of scholars studying cashlessness as a global phenomenon lifted the scales from my eyes. ${ }^{3}$ Beyond my own participant observation in Sweden's increasingly cashless economy, I was able to conduct in-depth interviews with parliamentarians, consultants, and governmental employees who were all intimately involved in the e-krona project (unfortunately, I never managed to speak with anyone inside the Riksbank itself, but multiple reports and video presentations published by the Riksbank provide a great deal of context). My employment at the Stockholm Centre for Organizational Research, along with standard volunteer work (e.g., garage sales) for my children's schools and extracurricular activities, provided me with many opportunities to discuss the cashless transformation with a wide variety of Swedes. I also kept a keen eye on daily transactions in a variety of settings, and peppered cashiers, bankers, bus and taxi drivers, and the like with questions about the transformation of payment platforms in Swedish society. Finally, I worked through copious public documents issued by various levels and branches of government, industry groups, commercial banks, and the Riksbank itself. It is worth noting that many of these documents are intentionally "in conversation" with one another, in keeping with a long Swedish tradition regarding governmental transparency and responses to the white papers that it issues. 
All this data comes together to portray the fight over nationalized e-cash and its future implications. By detailing not only how and why the Swedish cash krona is falling into abeyance but also the exclusionary consequences of losing cash as a public good, this article affirms the work of a long line of other researchers in showing how money serves as a "memory bank" of credit/debt transactions — "a record of all manner of relationships of credit and debt across time and space, and not just economic relationships of credit and debt" (Maurer 2017; see also Hart 2001). But because the crisis of the cash krona so lucidly illuminates that this memory-bank function of currency can be grounded in, and regulated by, either commercial banks or public authorities, it offers an opportunity to trace the many chains of credit/debt that help create this vast memory bank.

What entity - public or private — gets to acquire the almost "transcendental" status of grounding the value of a currency, as well as the immense social power of credit/debt issuance that comes with that status? $?^{4}$ Achieving this status - and holding one's place there - requires much engineering and nurturing, in the form of banking regulation, money markets, state financing and the like, all of which contribute to building a sort of "tethering mechanism" that helps forge vertical links of credit/debt between currency-issuing banks and the people who use them (see Ingham 2004). Following Bill Maurer (2016, 209), we must ask, "Who writes and controls these accounts? How are they ordering and re-ordering the world?"

\section{THE CURRENCY TETHER}

By previously choosing to settle many daily debts with hard cash, Swedes were all agreeing — whether they cared to know it or not — to walk around with the state's debt in their pockets and purses. But in their increasingly cashless world, Swedes are now choosing to walk around with the issued debts of new parties, tethering themselves to these private institutions rather than the state. And thus, the ongoing cashless revolution — both in Sweden and elsewhere — will not challenge the binding capacity of currency, but it is threatening to reconfigure those binds quite substantially.

So-called high-powered money serves as one anchor of this tether, as it stretches out and wends its way through a given population. High-powered money is composed of both all hard cash in the system and the digital central bank reserves that commercial banks must hold as part of their reserve requirements (in a fractional reserve system) (Ingham 2004, 141-44). As a direct debt claim on the central bank, it forms the "monetary base" that can then be leveraged by commercial banking institutions to create the remaining money supply (often, but not 
always, as high as 90 percent). This monetary base robustly circulates among users precisely because it is always tethered to the central bank and thus remains (in Ingham's terms) the "most reliable promise to pay." In this sense, national currency emerges out of far older traditions of "tallying” (see Maurer 2016); namely, cash leaves the central bank as a liability on its balance sheet (an easily transferable IOU), and this liability only disappears when the cash returns home. As Maurer (2017, chapter 12) tells us, "when people write IOUs, relations of credibility extend outward from person and paper. ... When states issue currencies, they leverage their own credibility in a financial and moral sense."

This is, as many have emphasized, a semiotic system - high-powered money, in the form of cash, works because people recognize and interpret these paper testimonials of the state's debt as the easiest debt to trade on a daily basis. Cash, with its many engravings and embossings, stands as a Peircian index, clearly pointing to the bank that issued it. Insofar as the bank is trustworthy, it gives rise to an interpretant, in the form of, "I can accept this as payment." During this ongoing process of semiotic-cum-economic exchange, it gradually creates what Paul Kockelman $(2013,3)$ helpfully refers to as an "ontology" that can be "understood as ensembles of assumptions regarding the underlying constitution of, or salient patterns in, the world." Over time, these (always provisional and contested, as Kockelman explains) patterns can then congeal to support, or even create, infrastructure (Kockelman 2013; see also Kockelman 2016). In the case of currency, it can smooth out transactions across given spaces and times, lending immense efficiency and increased clarity to the economic system, while also binding people together with a shared unit of measure.

But despite people's subjective experience of it, Sweden's popular and transferable digital money is not high-powered money, that is, money issued by the central bank and therefore a direct liability on its balance sheet (what the Riksbank calls centralbankspengar, or "central bank money"). Instead, it is a liability (a transferable IOU) on the deposit institution's balance sheet (what the Riksbank calls affärsbankspengar, or "commercial bank money"); commercial banks issue their own money in the Riksbank's unit of account, merely promising to use their own reserves of high-powered central bank money to immediately exchange any given customer's commercial bank currency "at par" for central bank currency should she ever want to convert her digital money into hard, national, cash. The Swedish Bankers' Association affirms this in its response to the e-krona project when it states, "for the general public, central bank money and commercial bank money 6 are normally seen as completely equivalent” (Svenska Bankföreningen 2018, 4). 
In other words, on a daily basis, cash users operate under the assumption that cash severs ties by allowing them to become quits in their debts with one another, just as Georg Simmel (1978) enthusiastically explained. Nevertheless, at these moments, they misrecognize the fact that they are simultaneously building or retaining a tether with the currency issuer, whether public or private. The IOU is not dissolved, only transferred to a new party. Currency, as many have long noted, is therefore itself a form of misrecognized credit/debt, which means that it can create and sustain the same binding ties that anthropologists typically find in other credit/debt relations. ${ }^{5}$

National taxation systems and their temporal rhythms help form the opposing anchor of the currency tether, completing a credit/debt loop between citizen and state. A growing branch of economic theory, known by its acronym, MMT (modern monetary theory), insists that our standard understanding of taxation is completely misguided. Rather than taxation funding government expenditure, it merely clears banking reserves when they are in excess, as a tool of managing the money supply. For this reason, MMT'ers are labeled “chartalists," believing that taxation ultimately exists simply to force people to accept the government's chosen medium of exchange and unit of account (see Wray 2015; see Innes 1914 for an earlier variant of this argument). To employ an idiom more familiar to anthropologists, MMT'ers are simply applying the concept of colonial "head taxes" to all subjects who use a fiat currency (e.g., Worsley 1968, 36-48). In short, taxation sets in motion the government's declared monopoly on currency; since one must pay taxes in the government's currency, one must earn those same currency units out in the lived world.

Without concerning ourselves with whether MMT'ers are correct about the origin of government funding (or anything else, for that matter), we can still appreciate the powerful simplicity of their expansion of old anthropological arguments about colonial head taxes to the general population. Once stated in this manner, we can see that every legal transaction in a given currency carries with it a hidden orientation toward the payment of annual taxes - a debt owed to the state (i.e., the opposite of cash, which is a debt issued by the state). When we buy something at a store, we forget that the storekeeper is simultaneously buying the national currency from us; both parties are selling something, even though our language convinces us that one party is the buyer and one the seller. In other words, one must transact with private parties on a daily basis so that one can accumulate the proper resource (the national currency) to transact with the government on an annual basis. 
We can now see how daily currency usage might best be seen as a surprising variant of Elyachar's notion of "phatic labor." She argues that phatic labor (often everyday chitchat) "produces communicative channels that can potentially transmit not only language but also all kinds of semiotic meaning and economic value" (Elyachar 2010, 453). By engaging in phatic labor, communicators are creating essential social infrastructure for the community. Likewise, by simply using cash to become quits in their debts to one another, people are - without even really caring_-building up and sustaining a vast and consequential public good.

If such phatic labor-previously organized around the cash krona - truly moves to other channels, the Riksbank knows that its entire regulatory regime will come to a close. Fearing the loss of a "state-guaranteed payment mechanism," the Riksbank wants to explore re-braiding this fraying tether by providing such a payment mechanism electronically (Sveriges Riksbank 2018, 2). ${ }^{6}$ Aside from losing their regulatory hegemony, the Riksbank and others are worried about what nonfiscal norms and values might be lost if the cash krona disappears. But first we must see how quickly all this phatic labor is moving away from hard cash.

\section{A FRAYING TETHER}

Every resident of Sweden who checked their mail during the last week of May 2018 received a jarring government missive telling them to prepare for war or catastrophe. In twenty easy-to-read pages, the pamphlet, If Crisis or War Arrives, quickly laid out the preparations that should be made in all Swedish homes (Myndigheten för Samhällsskydd och Beredskap 2018). As President Trump came to power and nationalist backlashes swept across their neighbors, many Swedes had begun to feel uneasy about the future. Most prominently, the threat of Russia was on many lips during my time there in 2017-2018. Not only was Vladimir Putin seen as adding fuel to the nationalist fires, but the United States' new skepticism of the NATO alliance reminded people of centuries-old Russian threats. Against this backdrop of a latent and low-simmering fear, the Crisis or War brochure was received with a mixture of surprise and (it must be said, relatively minor) anxiety.

Included in the crisis-or-war checklist about things to always have on hand was "cash, in smaller denominations" (Myndigheten för Samhällsskydd och Beredskap 2018, 10). An employee at the Swedish National Debt Office explained the reasoning behind this to me, pointing out that if any sort of crisis or war comes, the mobile and digital payments system may well collapse and people will have to "revert" to hard cash. The Riksbank itself backed up this claim when it wrote, "electronic payments increases the risk of significant shocks to the pay- 
ment system should part of the infrastructure be incapacitated. . . . In a crisis or situation of financial unease, when demand for cash can be assumed to increase, it would take considerable time to set up efficient distribution of cash to different participants," especially if the commercial system that had supported the infrastructure for cash had been dismantled (Sveriges Riksbank 2017, 13; see also Ehrenberg and Jansson 2017, 8-9).

Why would the government have to remind people to have cash on hand? Because the government and other researchers were, at that very moment, producing copious statistics on just how little cash was in the hands of the Swedish populace (e.g., Arvidsson 2013; Kontanthanteringsutredningen 2014; Ehrenberg and Jansson 2017; Dillén et al. 2018). For example, the recently published Delbetänkande from the Swedish Riksbank informs us that "cash usage is diminishing rapidly in Sweden. This reduction is probably happening faster here than in any other country. ... Since 1950 the amount of cash in relationship to the GDP has fallen from circa $10 \%$ to circa $1.2 \%$ by the end of April 2018, which is the lower rate among all developed countries" (Dillén et al. 2018, 73).

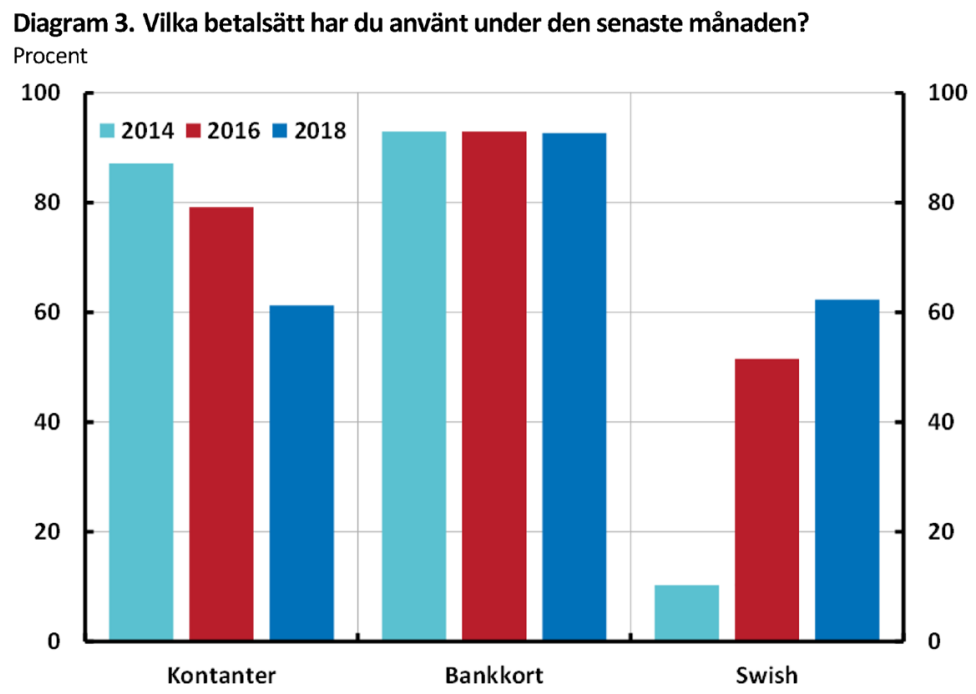

Källa: Riksbanken

Figure 2. Which payment technique have you used in the past month? Kontanter (cash), Bankkort (debit/credit cards), Swish. Graph from Sveriges Riksbank (2018).

In these reports, in formal and informal interviews, and in casual discussions with friends and colleagues, the sudden eschewing of cash is attributed to several reasons. First, Swedes often pride themselves on being early adopters of 
new technology (e.g., Kivra 2018; Savage 2018). But equally, the private infrastructure of electronic payments in Sweden has been built quite quickly, part of what Scott Mainwaring has dubbed the "Cambrian explosion in payments" (see Nelms et al. 2018, 14). As a result of these local and global trends, paying monthly bills and checking accounts by smartphone in Sweden has become exquisitely smooth, easy, and trustworthy, while the new Swish mobile app has made smaller payments between friends and exchange partners immediate and simple. This rapid shift to phone payments convinced one group of Riksbank experts to attribute accelerating cashlessness to consumer preferences (Sveriges Riksbank 2017, 10). In this account, cash is simply being outcompeted by fiery upstarts that trump it in terms of cost, convenience, and efficiency. Phatic labor still abounds, but it is nurturing and building new communicative channels.

Other contributors to the cashless revolution are also mentioned - by both the Riksbank and people with whom I spoke — such as the surprising campaign by the Shopworkers Union, which aimed to reduce cash holdings in stores so as to reduce robberies and threats to personnel. Bank employees pushed forward a similar campaign, leading many banks across the country to achieve an almost oxymoronic status as cashless banks. Several unions and interest organizations also joined together for a campaign to make the country cash-free. Starting in 2009 with the webpage "Kontantfritt.nu" (cashfree.now), they advocated on the streets, in the media, and even with fun contests to convince people to stop using cash (Klint 2009).

Other experts explain that the weak legal tender law in Sweden has facilitated the migration away from cash by shopkeepers (Sveriges Riksbank 2017, 11). Because shopkeepers have the right (already tested in the courts) to deny legal tender, Niklas Arvidsson (the premier scholar of cashlessness in Sweden) asserts that by 2030, 66 percent of stores and restaurants in Sweden will no longer accept cash at all (Blume 2017). As evidence of Sweden's toothless legal tender law, simply witness the countless stores that have placed variants of a sign that says, "This boutique is cash-free." Or what of the argument I witnessed at one café, where a young man became incensed that his cash proved unacceptable as payment. He took pains to describe to the cashier why hard cash was a legal means of payment, pedantically informing her, "but this is money." His lessons fell on deaf ears, and he stormed off from the establishment.

Finally, one parliamentarian from the Left Party told me that the "shift [to cashlessness] has been driven by banks, not citizens or even the market." In this regard, he complained about the seizure of a public good by private actors: 
Sweden is a very privatized country. . . . The mint for the bills is run by a company ... the depots [needed for circulating and storing cash] are owned by the big banks. This means that smaller, niche banks cannot break into the market - they must go through the big banks' depots, so this is a natural monopoly that should theoretically be owned by the state, but is held in private hands.

A standard and typical opponent of the Swedish Left Party, the premier Swedish business lobbying group Svenskt Näringsliv, also provides more background on this important fact:

The reason so many fin-tech companies emerged in Sweden in particular can be explained by the Riksbank's decision at the end of the 1990s to pass the lion's share of responsibility for handling cash over to the banks. Because the banks were [suddenly] forced to carry most of the costs of handling cash, they had every reason to develop payment mechanisms that were more efficient [than cash]. (Svenskt Näringsliv 2019, 3)

Both quotes describe a quintessentially neoliberal reform, wherein the Riksbank chose to offload vital public infrastructure to the private market so as to save money and (theoretically) improve efficiency. Commercial banks made money from this reform, but as the internet became consolidated, they realized they could save even more money by abandoning cash altogether. As one businesswoman suggested, ironically, to me (when discussing the newfound benefits of digital payments), "the banks don't want to touch money!"

This brings us back to the café owner whom we met at the beginning of this article. His critique of the arrival of cashlessness, and why he is taking a stand against it, precisely targets this moment when banks became perversely incentivized to push Swedes to abandon cash-incentivized by the producer of cash itself. He recounted a trajectory that began with customers paying an extra fee for each digital payment, but then ended with the current situation, wherein the proprietor pays a fee. He claimed that the banks were intentionally hiding the cost of electronic transactions from their customers in an effort to push them onto commercial banking's digital platforms and away from the attendant costs (to the banks) of hard-cash transactions. He considered this a devious ruse, so he responded by refusing to ever accept digital payments again. His commentary forces us to recognize that storing and using money costs money and carries risks, whether in a 
pocket or on a smartphone. The expenses associated with these different modalities of using money, however, are not purely economic ones, as we must explore now.

\section{EXCLUSIONARY TETHERS}

One restaurateur, who kindly gave me an entire lesson on the evolution of payment structures in Sweden, simultaneously critiqued and celebrated cashlessness. On the one hand, she believed that the facility of the phone app, Swish, had opened up new social pathways of kindness among strangers who had ignored each other in the past. But while she noted this new fluidity between citizens, she pointed out that the same generosity was no longer operative between citizen and private industry. In so doing, she connected the privatization of the means of payment with the privatization of the public square, explaining that "they are taking a little money for everything [as opposed to a lot for a few things]. The town square is getting glassed in more and more." She saved her severest critique for how public toilets had suddenly become closed off to countless citizens: "They can only be unlocked with a card; it's a completely inhumane society, excluding children, the elderly - everyone who isn't in the middle of their lives and careers."

In complaining of this interrelated cascading dispossession (see Harvey 2003) of both public cash and public infrastructure, she was not alone. I also heard the example of locked bathrooms from at least three different people. I even experienced it myself: On leaving one of them one day, a man asked if he could use it after me, without paying first. I held the door open for him so that he would not have to pay; on leaving, I noticed that five additional toilets had been vacant, but the man had opted to wait for mine in the hopes of free entry. It is possible that he was choosing to save money, but it is equally possible that he simply did not have the capacity to pay with a card. ${ }^{7}$

The people I met who were concerned about the evolution of cashlessness mostly sought to critique it from this standpoint, that it introduced antidemocratic and pro-hierarchical forces into a Swedish society that prided itself on its egalitarianism. Without turning to the technical term public goods, they would lament the loss of the egalitarian space that the national currency had produced, bringing urban, rural, rich, and poor Swedes all together in a common space of currency usage and access. Now, they feared that cashlessness was creating new social boundaries via what has been christened "digital outsidership" (see, e.g., Ehrenberg and Jansson 2017). ${ }^{8}$ 
Not surprisingly, members of the emergent cashless society have already agreed to levels of digital surveillance that, per definition, can only be offered to well-established insiders. For example, to acquire Swish, one must first have a bank account (and a smart phone, with a phone account). But to acquire a bank account in Sweden, one must already have a personal ID number, which is an intensely bureauacratized process for immigrants and refugees (native Swedes are, quite literally, born with them). This scenario perfectly encapsulates Brett Scott's (2019) argument that "cashless" always carries with it the hidden meaning of "bankful," because one cannot be cashless — at least currently in Sweden — without being banked. Quite tellingly, in Stockholm one can find people asking for money on the street, some of whom can accept a donation via Swish, and some of whom cannot. Swedes typically characterize the former as drug-dependent locals while, due to the traditional clothing they wear, they see the latter as non-local Roma; one group has access to the precious state documents that allow them to acquire Swish, while the other group does not. As such, the same economic activity_asking for money on the street — can be split into insider/outsider groupings by those who witness it. Because such a phenomenon is so reminiscent of the "beggars' passes" common in many European towns during the Middle Ages, it stands as still more evidence that digital cash is threatening the modernist Swedish ethos organized around egalitarianism with a more premodern ethos of hierarchy (see Levander 1974; Harrington 1999; Peebles 2011, chapter 4).9

Mindful of this infrastructure that supports cashlessness, I set out to speak with the people who run Situation Stockholm, the magazine sold by the local homeless population. I had noticed that their salespeople were now taking payment via Swish, so I wanted to hear more about how this traditionally outcast salesforce had become banked. The editor-in-chief informed me that, indeed, her customer base had stopped using cash, forcing the magazine to join the cashless world to hold onto its customers. But she admitted that this new system only allowed her to hire sellers with personal ID numbers.

While she was explaining this to me, she mentioned other groups that cashlessness has left behind - the elderly who cannot "catch up" with the latest technology, people with disabilities who cannot use smartphones (e.g., the blindwhereas cash bills in Sweden are all different sizes, to accommodate the blind), and people who live deep in the countryside and therefore have poor connectivity to the internet. These same concerns were voiced by the parliamentarian Ulla Andersson in a forceful letter to a cabinet minister, where she spoke of many people (especially elderly, disabled, and rural people), businesses, and civic organiza- 
tions who all desperately need hard cash — and the public infrastructure to help circulate it - to keep their daily affairs going. Andersson (2016) accused a recent government investigator of "completely neglect[ing] the actual problems that exist today" in a cashless economy for these many groups.

But the taint of digital outsidership has metastasized far beyond more traditional markers of social marginality. As the restaurant owner I spoke with described the speed with which cash had disappeared, she hazarded a guess that a mere 1 percent of her sales today occurred in cash. But then she quickly corrected herself, explaining that this rose to 5 percent during the summers. I wondered why this was the case. Because, she explained, tourists arrive without any idea that Sweden is largely cashfree, so they mistakenly acquire cash at the airport on arrival, cash they must unload before leaving the country again. If cash used to be famed for its anonymity, allowing both insiders and outsiders to be engaged in trades without a care for origin, today in Sweden it can be a relatively reliable marker to distinguish between locals and foreigners - people who are just passing through from those who are residents.

Increasingly, cash also often marks its users as likely members of the criminal underground. Once, when buying strawberries from a local vendor, I spoke to the woman about her recent ability to accept payment via Swish. She said she was happy to take Swish, but she was sad to see the evolution of moral critiques against cash. She explained that, given her job, she still carries around large amounts of hard cash. She then told me a story of how she had tried to purchase some goods in a store once with her hard-earned cash; the cashier had refused her money, stating, "Sorry, we don't take black money [i.e., money earned illegally]." She was appalled, explaining that Sweden's public cash had now fallen so low in people's estimation that it is associated with rank criminality, rather than the hard labor in the hot sun that she herself undertakes.

\section{DIGITIZING THE TETHER}

With this general decline in both the amount of cash in use and the opinions directed toward it, the Riksbank had decided to boldly defend its monopoly position on two fronts. First, it issued a report that included a new ethical and pragmatic demand that commercial banks be forced to circulate the Riksbank's hard cash at the commercial banks' expense (whereas the late 1990s reform, described earlier, allowed banks to make money from the movement of cash, since it was then still a popular currency). The report bluntly insists that "it is not reasonable that the banks can completely abandon their responsibility for handling a given 
form of the medium of payment, as long as there exists a need for it in society" (Dillén et al. 2018, 148). Insofar as one of the services that these regulated banks provides is "access to cash," the Riksbank deems it fair to insist that these banks should provide that service in exchange for the privilege of being a licensed bank.

At the same time, several reports and public statements issued by the Riksbank and its workers seem to acknowledge that there is only so much it can do to push its old and original product (the metal and paper krona) onto the commercial banks and consumers who have already walked away from it. Instead, it seems to be acknowledging its preordained failure and wants to spruce up its main monopoly product — cash. As it falls out of favor, perhaps it is time to reinvigorate it and make it more appealing. Keep up with the times, as it were.

And thus, a wing of the Riksbank has proposed a national digital currency, the e-krona. Initially, the e-krona sounds humdrum and boring-why would it be hard to replace notes and coins with digits? In fact, the Riksbank consultant with whom I spoke told me that the distribution of cash had long been relegated to a low-status wing of the Riksbank. The "real brains" and the ambitious people were all in the production side of money-fine-tuning interest rates, monitoring bank policy, and mapping the broader contours of monetary policy in a globalized world. Against this, figuring out how to move cash around the country was considered the vocational-tech side of central banking.

But quite suddenly, revolutionary digital currencies have caused the distribution side of monetary policy to rise in stature. As Taylor C. Nelms et al. $(2018,16)$ would say, digital currencies propose "not just to ride the old rails but build wholly new ones." For this reason, digital currencies fascinate many monetary theorists, since they loom as a system-threatening inevitability that must be addressed. To understand why that might be so, we have to understand that the transformative power of the e-krona only becomes clear once one investigates the seemingly mundane question of value storage.

Consider paper money, lowly and tattered. We are accustomed to celebrating (or defaming) its potential for anonymity, but we are less accustomed to realizing that this anonymity exists only because it has already been de-tethered from its previous storage facility. A transfer from one bank account to another is clearly labeled and traceable to various points of origin - us, the commercial bank, the central bank, and so on. However, once it has been removed from our commercial bank's storage, it relocates to new storage facilities such as our pockets, our wallets, our mattresses, while simultaneously falling off the commercial bank's accounting ledger. This process de-tethers the commercial bank intermediary from 
the currency, making the latter anonymous, but also revivifying the claim against the central bank that originally issued it. Cash is a walking, anonymized line item, tethered to a distant ledger; even though it appears to be detached from any balance sheet, it is accounted for in the double-entry system of the central bank as an outstanding liability.

Thus, the heyday of cash meant that pockets, wallets, and mattresses all stood as competitive alternatives to deposit banks. The former serve as "banks" for central bank money, whereas the latter serve as banks for commercial bank money. But since these two variants of national money trade at par, Swedes have blithely ignored this vital distinction — or rather, the infrastructure was intentionally built so as to elide this distinction. In Sweden's emerging world of digital payments, pockets have lost their use-value as personal depository institutions of central bank money; instead, when Swedes keep e-money on their person today via a smartphone, credit card, or debit card, they are holding commercial bank money. ${ }^{10}$

And thus, the current problem with e-cash, as the recent Riksbank reports clarify, is that it can never be a walking ledger unto itself. Rather, it only works inside a collectivized storage facility. Unlike hard cash, which indexes (again, in the Peircian sense) its tethering mechanisms with its beautiful and hard-to-counterfeit filigreed designs, its serial numbers, and its watermarks, digital cash can only index its tethering mechanism by being held inside a sanctioned ledger. Payments with e-krona could easily move back and forth between buyers and sellers, but only if both parties held accounts inside the communal ledger. Like all money, its functionality is fundamentally tied to particular modes of storage, but in this case, there is, as yet, no non-private institution where personal stashes of national e-money could be held.

On multiple occasions, the Riksbank insists that any new e-krona will have to "function independently of the commercial, bank-owned infrastructure," just as traditional cash does today (Sveriges Riksbank 2017, 16). Without this capacity, it cannot combat the "walled gardens" inherent in the commercial banking system (see Maurer 2017), which many fear are growing (as described earlier). It therefore must grapple with how to get this new e-cash into the hands of its users. Confronted with this predicament, the Riksbank has come to the surprising and shocking conclusion that "the introduction of an e-krona could, regardless of the choice of model, lead to the Riksbank introducing services aimed at the general public. This is a significant change compared with its current operation, in which it has no direct relationship with either consumers or other end-customers" (Sveriges Riksbank 2017, 23). ${ }^{11}$ 
Significant might fairly be described as an understatement of the first order; epochal would be more appropriate. Today's central banks do not provide services directly to citizens, but rather to the commercial banks that citizens use. The e-krona, however, radically necessitates the creation of individual accounts at the Riksbank itself (Sveriges Riksbank 2017, 16). Cash, whether hard or digital, creates a so-called settlement platform, but e-krona could only manage this by providing users with accounts. As the Swedish Finance Inspection Office puts it, "The Riksbank would therefore no longer only be the banks' bank, but also the general public's bank" (Finansinspektionen 2019, 9).

And once a central bank is offering a smooth and reliable settlement platform to private citizens (e.g., as the Riksbank suggests, perhaps via an app on one's smartphone), it suddenly raises the question of why anyone would ever need a commercial bank at all. If the storage-cum-payments mechanism stands as the primary reason that people have accounts at commercial banks, then, the Riksbank predicts - quite reasonably_commercial banks could experience a vast drain of deposits. As a simple result of their reliance on a specific storage location, e-kronas would set in motion a sort of technological determinism that could cause profound changes in Swedish banking. Indeed, the Riksbank's reports hint in multiple locations that it would suddenly be competing with the commercial banks for customers, even by potentially lending directly to them (Sveriges Riksbank 2017, 35). Consequently, commercial banks would have to offer shiny new things-higher interest rates and financial innovations - to convince people to bother keeping their money with them. In other words, the dangerous irony of the e-krona could be that it would finally cause the citizenry to start noticing the difference between central bank money and commercial bank money that lies at the heart of national money's misrecognition mechanism as described above (see also, e.g., Sparbankernas Riksförbund 2018, 2).

Overall, the responses from private industry groups to the Riksbank's e-krona proposal pointed out multiple ways in which the e-krona could prove profoundly unstable to Swedish banking, undermining the very purpose of central banking itself. One highly placed interlocutor told me that the Riksbank had brought its "B-Team" to the project, and had failed to think through several foundational issues, such as the explosion of the Riksbank's balance sheet as people suddenly start asking for all their money to be in central bank money rather than commercial bank money (see also Finansinspektionen 2019, 9-10). The Swedish Union of Savings Banks revealed similar disdain: After it posited that even mentioning the e-krona could prove destabilizing (since it would suggest to people 
that there are weaknesses in commercial bank money that are necessitating its invention), it stated that "the Union regards the question of an e-krona as the embryo of a conceptually incomplete idea, far from the concrete fleshing out that is demanded" (Sparbankernas Riksförbund 2018, 52).

And yet, central banking operates on the principle of Carl Schmitt's (2005) "sovereign exception" — precisely that it stands as "the banks' bank." This structure allows it to be the only entity that can issue high-powered money, as well as the only entity that can serve as the "lender and hoarder of last resort." In some ways, central banks achieve their goals by serving as a "transcendental signified" of the entire banking system, grounding it by being both inside and outside of it simultaneously (Peebles 2014). But if the e-krona brings the Riksbank into the world of mundane citizen-to-citizen, business-to-business, and citizen-to-business payments, it could either be sullied as just a "regular bank" or it could just as easily eliminate all the other banks it typically aims to support. Indeed, these two potential outcomes are harmonic, rather than mutually exclusive.

\section{CONCLUSION: Currency Tethers in a Seemingly Post-National World}

While potentially destabilizing commercial banking and threatening its profits, the e-krona would also greatly reduce the power of its tethering mechanism in daily society. As commercial banks' tethering mechanism frayed, the Riksbank's would grow even stronger than it had been during the reign of paper money, by taking on millions of Swedes as direct customers. And thus, just as private toll roads often gave way to public toll-free highways in many countries, the e-krona cracks open the door to a radical reconfiguration in the movement and storage of capital. It is surely too drastic to predict the demise of worldwide commercial banking if other countries follow Sweden's lead and consider releasing digital currencies of their own. And yet, esteemed economists (and crypto-skeptics) such as Nouriel Roubini (2018) have suggested that this could lead to nothing less than a financial revolution, undermining the entire public-private fractional reserve banking system on which the world has come to rely.

Of course, countless other outcomes are possible — and even likely-for Sweden's cashless future and for those who must navigate it. Either way, however, we can see that the Riksbank is caught on the horns of a dilemma. On the one hand, "the Riksbank has the statutory task of promoting a safe and efficient payment system and of providing Sweden with banknotes and coins. . . the possibility to complete these tasks may deteriorate if developments on the payment 
market continue" (Sveriges Riksbank 2017, 39). In other words, if it does not act, the Riksbank may no longer be able to complete its most vital tasks, all of which ground the entire national banking system. On the other hand, if it does act, it may end up knocking down this same banking system, one the Riksbank was originally designed to sustain.

There is every reason to believe that, in the near future, all central banks will be confronting this dilemma. ${ }^{12}$ After all, myriad public goods have come and gone before. Many countries will be entering into periods of robust debate about whether they want to nurture and sustain the clear methods required to retain national currencies as public goods, as against the many new private ones now proliferating. As we have seen, currency as a public good falls away without monopoly issuance, for the central bank requires the credit/debt loop between citizen and state to be not only forged but also sustained on a daily basis by the phatic labor of millions of quotidian purchases.

Given this, the Riksbank's battle to retain the relevance of its primary product in the face of newfound competition provides us with a stark glimpse of how all national currencies exist as the outcome of both collaboration and competition between commercial and public banks. We frequently are wont to see central banks as intimately working in tandem with the commercial banking infrastructure that they are designed to support, but anthropologists must also pay close attention when breaches in these often cozy relations emerge, as is so clearly happening in Sweden today. For these breaches can signal the incipient privatization and dispossession of public currency itself, pushing people into newly privatized zones of exchange and away from more universally available public ones.

\begin{abstract}
As cash has suddenly gone missing from Swedish life, a growing range of citizens and institutions have sounded the alarm that cash enabled a space of egalitarian access now under threat. But because commercial bank currency is gradually displacing public central bank currency, cashlessness in Sweden is not only threatening its egalitarian ethos but also the Swedish Central Bank's capacity to provide a guaranteed state payment mechanism. The consequences of Sweden's battles over cash-issuance may presage the future of our global banking system in a digital age, while also illuminating what is here called currency's "tethering mechanism.” Because bank-issued currencies represent chains of credit/debt, exchanging and storing different currencies can tether and de-tether their users to different institutions, thereby offering anthropologists the possibility of mapping the waxing and waning of various dominant so-
\end{abstract}


cial institutions. [cash; central banking; infrastructure; digital money; storage; public goods]

\section{SAMMANFATTNING}

Det svenska samhället har bara på några år kommit att bli ett kontantlöst samhälle. Nu larmar institutioner och medborgare om att bristen på kontanter hotar möjligheten för invånare att delta i samhället på ett likvärdigt sätt. Det kontantlösa samhället hotar inte bara dess jämlikhetsetos utan också den svenska centralbankens förmåga att tillhandahålla en garanterad statlig betalningsmekanism då affärsbanksvaluta gradvis förskjuter den offentliga centralbanksvalutan. Det svenska banksystemet fungerar därför som ett bra exempel utifrån vilket vi kan förutse konsekvenserna av ett kontantlöst globalt banksystem, samtidigt som det också kan belysa det som här kallas valutans "tethering mechanism". Utbyte och lagerhållning av olika valutor kopplar eller skiljer användare till eller från olika institutioner, eftersom bankemitterade valutor representerar kedjor av kredit/skuld. Det ger antropologer möjlighet att studera och kartlägga dominerande sociala institutioners uppgång och fall. [kontanter; centralbank; infrastruktur; digitala pengar; lagring; kollektiv vara]

\section{NOTES}

Acknowledgments I would like to thank my colleagues at the Stockholm Centre for Organizational Research, as well as other colleagues at Stockholm University, for both hosting and providing institutional support during my year in Sweden; in particular, Renita Thedvall not only aided me throughout the year, but also helpfully copyedited the Swedish version of the abstract for this article. For much-needed inspiration, I am also indebted to the many participants of the new project, "After Money, What Is Debt?" run from the Copenhagen Anthropology Department by Atreyee Sen, Camilla Ida Ravnbøl, and Marie Kolling. I am also thankful to the insightful anonymous reviewers and helpful editors of Cultural Anthropology. Finally, I would like to thank Léa Coffineau for her research aid.

1. There is a copious literature on so-called public goods. Quickly, they represent zones of market failure - vital economic services that cannot be provided by the market because they suffer two central problems: 1) They are non-excludable, that is, the free-rider problem emerges, wherein people can use the service or good without paying for it, and 2) They are non-rivalrous, that is, the usage by one person does not impact the quality of service that another person receives (see, e.g., Kaul, Grunberg, and Stern 1999). As a result of these issues, public goods often need to be "natural monopolies" (in an older idiom; see Norton 2008) owned by the collective, which has, of course, been the case with national cash in countless countries for more than a century.

2. All translations from the original Swedish are my own.

3. I thank Marie Kolling, Johan Lindquist, Camilla Ida Ravnbøl, and Atreyee Sen for raising my awareness of the issue. A recently published volume (Sen, Lindquist, and Kolling 2020) documents some of their extensive efforts to date.

4. Though she was not concerned with national currencies or banks, I here take inspiration from Annette Weiner's arguments about "inalienable possessions" (see Weiner 1992). I have previously outlined the ways in which Weiner's arguments can help us better understand banking (see Peebles 2014). 
5. The notion that state currencies are merely the monetized debt of the state has long been argued by a range of scholars and central bankers (a reliable historical survey can be found in Ingham 2004, chapter 2; see also Wray 2015; Aglietta 2018). Outside of economics, see also, e.g., Patrick Brantlinger (1996) and Christine Desan (2015). The idea has even broken into the mainstream, when the hashtag \#mintthecoin went viral in 2012-2013 (see https://en.wikipedia.org/wiki/Trillion_dollar_coin).

6. See Adam J. Levitin (2009) for an early argument that the U.S. Federal Reserve should start competing in the digital payments market.

7. I covered some additional aspects of cash usage from the perspective of race, class, and the urban/rural divide in a contribution to a Hot Spots series (Peebles 2019).

8. Though it might sound like a term of art by social scientists or technocrats, in Sweden, the term outsidership (utanförskap) circulates among the general population more than perhaps it might in many other countries.

9. More recently, digital outsidership reared its head prominently in the recent Indian demonetization (see Dharia and Trisal 2017), and is also attested to in a variety of settings around the world (see, e.g., Maurer, Musaraj, and Small 2018; Sen, Lindquist, and Kolling 2020).

10. Seen from this perspective, the recent EU directive on "payment services" (Directive 2015/2366) can be seen as a European-wide acknowledgment that cash is moving from a public good to a private one, and that laws must be enacted to ensure that private companies cannot actively keep people out of the public square.

11. Nouriel Roubini (2018), as well as a Bank for International Settlement report (Committee on Payments and Market Infrastructures, Markets Committee 2018), back up this account for other countries outside of Sweden.

12. As testimony to this, it is worth noting that the United States Congress recently included the idea of "FedAccounts" in an early draft of legislation for its COVID-19 response. This would have directed the Federal Reserve to open up "digital dollar" deposit accounts for ordinary citizens directly at the Federal Reserve Bank (see Shelton 2020).

\section{REFERENCES}

Aglietta, Michel

2018 Money: 5,000 Years of Debt and Power. Translated by David Broder. London: Verso. Andersson, Ulla

2016 “Interpellation till Statsråd.” Sveriges Riksdag. 2015/16:376 Kontanthantering. February 5.

Arvidsson, Niklas

2013 "Det kontantlösa samhället: Rapport från ett forskningsprojekt." Stockholm, Sweden: Institutionen för industriell ekonomi och organisation, Kungliga Tekniska Högskolan.

Blume, Ebba

2017 "Majoritet av handlarna kommer vägra kontanter." $S_{v} D$ Näringsliv, August 8. https://www.svd.se/majoritet-av-handlarna-kommer-vagra-kontanter.

Brantlinger, Patrick

1996 Fictions of State: Culture and Credit in Britain 1694-1994. Ithaca, N.Y.: Cornell University Press.

Committee on Payments and Market Infrastructures, Markets Committee

2018 "Central Bank Digital Currencies." Basel, Switzerland: Bank for International Settlements.

Dalinghaus, Ursula

2017 "Keeping Cash: Assessing the Arguments about Cash and Crime." White Paper. Irvine, Calif.: Institute for Money, Technology, and Financial Inclusion.

2019 "Virtually Irreplaceable: Cash as Public Infrastructure." White Paper. Irvine, Calif.: Institute for Money, Technology, and Financial Inclusion. 
Desan, Christine

2015 Making Money: Coin, Currency, and the Coming of Capitalism. New York: Oxford University Press.

Dharia, Namita, and Nishita Trisal, eds.

2017 "Demonetization: Critical Responses to India's Cash(/less) Experiment." Hot Spots, Fieldsights, September 27. https://culanth.org/fieldsights/series/ demonetization-critical-responses-to-indias-cash-less-experiment.

Dillén, Matts, Janine Alm Ericson, Dennis Dioukarev, Jonas Jacobsson Gjörtler, Johan

Lönnroth, Fredrik Olovsson, Bosse Ringholm et al.

2018 Tryggad tillgång till kontanter: Delbetänkande av Riksbankskommittén. Statens Offentliga Utredningar [SOU] 2018:42. Stockholm, Sweden: Norstedts Juridik.

Ehrenberg, Sara, and Johanna Jansson

2017 Bevakning av grundläggande betaltjänster. Länsstyrelsen Rapport: 13.

Elyachar, Julia

2010 "Phatic Labor, Infrastructure, and the Question of Empowerment in Cairo." American Ethnologist 37, no. 3: 452-64. https://doi.org/10.1111/j.1548-1425. 2010.01265.x.

Finansinspektionen

2019 “Remiss av e-kronaprojektets delrapport 2.” Stockholm.

Grossman, Richard S.

2010 Unsettled Account: The Evolution of Banking in the Industrialized World since 1800. Princeton, N.J.: Princeton University Press.

Harrington, Joel

1999 "Escape from the Great Confinement: The Genealogy of a German Workhouse." Journal of Modern History 71, no. 2: 308-45. https://doi.org/10.1086/235249.

Hart, Keith

2001 Money in an Unequal World: Keith Hart and His Memory Bank. New York: Texere. Harvey, David

2003 The New Imperialism. New York: Oxford University Press.

Helleiner, Eric

2003 The Making of National Money: Territorial Currencies in Historical Perspective. Ithaca, N.Y.: Cornell University Press.

Holmes, Douglas R.

2014 Economy of Words: Communicative Imperatives in Central Banks. Chicago: University of Chicago Press.

Ingham, Geoffrey

2004 The Nature of Money. Cambridge, UK: Polity.

Innes, A. Mitchell

1914 “The Credit Theory of Money." Banking Law Journal 31, no. 1: 151-68.

Kaul, Inge, Isabelle Grunberg, and Marc A. Stern, eds.

1999 Global Public Goods: International Cooperation in the 21st Century. Oxford: Oxford University Press.

Kivra

2018 "Cecilia Skingsley på Kivras digitaliseringsmöte.” YouTube, December 18. Video,

Klint, Linnéa 14:30. https://youtu.be/_-g9GYaIfS8.

2009 "Facket ordnar tävling för kontantfritt." Handelsnytt, October 15. https:// Kockelman, Paul handelsnytt.se/2009/10/15/facket-ordnar-tavling-for-kontantfritt/.

2013 Agent, Person, Subject, Self: A Theory of Ontology, Interaction, and Infrastructure. New York: Oxford University Press.

2016 The Chicken and the Quetzal: Incommensurate Ontologies and Portable Values in Guatemala's Cloud Forest. Durham, N.C.: Duke University Press. 
Kontanthanteringsutredningen

Levander, Lars

2014 Svensk kontanthantering: Betänkande av kontanthanteringsutredningen. Statens Offentliga Utredningar [SOU] 2014:61. Stockholm: Fritzes.

1974 Fattig folk och tiggare [Poor people and beggars]. Stockholm: Gidlunds Förlag. Originally published in 1934.

Levitin, Adam J.

2009 "Public-Private Competition in Payments: The Role of the Federal Reserve." Georgetown Law and Economics Research Paper No. 1420061. http://ssrn.com/ abstract $=1420061$.

Maurer, Bill

2015 How Would You Like to Pay? How Technology Is Changing the Future of Money. Durham, N.C.: Duke University Press.

2016 "Cashless, Ancient and Modern." In The Archaeology of Money, edited by Colin Haselgrove and Stefan Krmnicek, 209-25. Leicester, UK: School of Archaeology and Ancient History, University of Leicester.

2017 "Money as Token and Money as Record in Distributed Accounts." In Distributed Agency, edited by N. J. Enfield and Paul Kockelman. Oxford, UK: Oxford University Press.

Maurer, Bill, Smoki Musaraj, and Ivan V. Small

2018 Money at the Margins: Global Perspectives on Technology, Financial Inclusion, and Design. New York: Berghahn Books.

Myndigheten för Samhällsskydd och Beredskap

2018 Om krisen eller kriget kommer: Viktig information till Sveriges invånare. Karlstad, Sweden: Stibo Graphic A/S.

Nelms, Taylor C., Bill Maurer, Lana Swartz, and Scott Mainwaring

2018 "Social Payments: Innovation, Trust, Bitcoin, and the Sharing Economy." Theory, Culture, and Society 35, no. 3: 13-33. https://doi.org/10.1177\%2F0263276417 746466.

Norton, Peter D.

2008 Fighting Traffic: The Dawn of the Motor Age in the American City. Cambridge, Mass.: MIT Press.

Peebles, Gustav

2011 The Euro and Its Rivals: Currency and the Construction of a Transnational City. Bloomington: Indiana University Press.

2014 "Rehabilitating the Hoard: The Social Dynamics of Unbanking in Africa and Beyond." Africa 84, no. 4: 595-613. https://doi.org/10.1017/S0001972014000485.

2019 “Cash Deserts and Cash Swamps." Hot Spots, Fieldsights, October 22. https:// culanth.org/fieldsights/cash-deserts-and-cash-swamps.

Rogoff, Kenneth S.

2017 The Curse of Cash: How Large-Denomination Bills Aid Crime and Tax Evasion and Roubini, Nouriel Constrain Monetary Policy. Princeton, N.J.: Princeton University Press.

2018 "Why Central Bank Digital Currencies Will Destroy Cryptocurrencies.” Project Syndicate, November 19. https://www.project-syndicate.org/commentary/ central-banks-take-over-digital-payments-no-cryptocurrencies-by-nourielroubini-2018-11.

Savage, Maddy

2018 "Thousands of Swedes Are Inserting Microchips under Their Skin." NPR, October 22. https://www.npr.org/2018/10/22/658808705/thousands-of-swedes-are-

Schmitt, Carl inserting-microchips-under-their-skin.

2005 Political Theology: Four Chapters on the Concept of Sovereignty. Translated by George Schwab. Chicago: University of Chicago Press. 
Scott, Brett

2019 "Will Paper Currency Become Obsolete in the United States? Con.” In "The Future of Cash: Will Digital Payment Systems Replace Paper Currency?” by Hannah H. Kim, CQ Researcher 29, no 26. http://library.cqpress.com/cqresearcher/ cqresrre2019071900.

Sen, Atreyee, Johan Lindquist, and Marie Kolling, eds.

2020 Who's Cashing In? Contemporary Perspectives on New Monies and Global Cashlessness. New York: Berghahn Books.

Shelton, Jordan

2020 "Digital Dollars: Amid the COVID-19 Crisis, Support for a U.S. Digital Currency Emerges." National Law Review 10, no. 100. https://www.natlawreview.com/ Simmel, Georg article/digital-dollars-amid-covid-19-crisis-support-us-digital-currency-emerges.

1978 The Philosophy of Money. Translated by Tom Bottomore and David Frisby. London: Routledge and Kegan Paul.

Sparbankernas Riksförbund

2018 “Yttrande över Riksbankens e-kronaprojekt delrapport 2.” Stockholm.

Svenska Bankföreningen (Swedish Bankers' Association)

2018 "Bankföreningens synpunkter på Riksbankens e-kronaprojekt delrapport 2." Stockholm.

Svenskt Näringsliv

2019 “Remissvar: Riksbankens e-kronaprojekt, rapport 2."

Sveriges Riksbank

2017 “The Riksbank's e-krona project.” Report 1, September.

2018 "Riksbankens e-kronaproject." Rapport 2, October.

Weiner, Annette B.

1992 Inalienable Possessions: The Paradox of Keeping-While-Giving. Berkeley: University of California Press.

Worsley, Peter

1968 The Trumpet Shall Sound: A Study of "Cargo" Cults in Melanesia. New York: Schocken Books.

Wray, L. Randall

2015 Modern Money Theory: A Primer on Macroeconomics of Sovereign Monetary Systems. Basingstoke, UK: Palgrave Macmillan. 